\title{
Irrational Suffering - An Impact of Cognitive Behavioural Therapy on the Depression Level and the Perception of Pain in Cancer Patients
}

\author{
Ewa Wojtyna \\ University of Silesia in Katowice \\ Poland
}

\section{Introduction}

International Association for the Study of Pain (IASP) provides the definition of pain according to which pain is an unpleasant sensory and emotional experience associated with actual or potential tissue damage, or described in terms of such damage (cf. Witte \& Stein, 2010). Therefore pain is a phenomenon which extends beyond the somatosensory dimension and its perception is determined by a number of factors, among which mental factors deserve special attention as they can be modified by psychological interventions.

Pain is not always confined to a physical sensation. In the following paper the term 'pain' is reserved for somatic pain. However, the experience of such pain might become a threat to the integrity of the self, which is accompanied by despair. The sensations of this kind will be described as 'suffering'.

\section{Pain in cancer patients}

Cancer patients commonly experience pain in various stages of their disease. Numerous studies indicate that approximately $1 / 3$ of the patients experience pain in the active stage of their disease, and the proportion rises to $50-78 \%$ in the advanced stages of cancer (e.g. Breitbart et al., 2009; Chapman, 2011). Approximately 33\% of cancer survivors suffer from a chronic pain syndrome as a result of tissue damage or as a side effect of their treatment (A.W. Burton et al., 2007; van den Beuken-van Everdingen et al., 2007).

A number of factors are responsible for pain experienced by cancer patients. Among the major ones is the development of the disease: tumour compression or infiltration of nerve, plexus and meninges as well as metastases to the bones. Approximately $25 \%$ of patients present with pain which is a side effect of radiotherapy, chemotherapy or surgical procedures (Breitbart et al., 2009).

Pain which develops as a result of radiotherapy is caused by skin burns and the reduced blood flow in the irradiated tissues, which may lead to necrosis, neural damage, fibrosis or stenosis. Post-radiotherapy pain occurs not only during the active treatment but also months and even years after the completion of the treatment (cf. Breitbart et al., 2009; A.W. Burton et al., 2007; Colyer, 2003). 
Chemotherapy-induced pain is commonly brought on by peripheral neuropathy as well as by the direct damage of the tissue susceptible to chemotherapeutic drugs, such as mucous membrane lining the digestive tract (Visovsky et al., 2007). Such drugs as platinum compounds, vinca alkaloids, taxanes, thalidomide and bortezomid tend to contribute to the development of neuropathy (Armstrong et al., 2005; A.W. Burton et al., 2007).

Pain resulting from the surgical procedures is commonly caused by tissue damage during surgery, scarring, adhesion, lymphoedema, neural damage (e.g. of axillary or intercostobrachial nerves), neuromas or phantom sensations following the amputation of the body part (Breitbart et al., 2009; Chapman, 2011).

\section{The psychological aspect of chronic pain in cancer patients}

\subsection{The consequences of pain for the patient's functioning}

Pain, and chronic pain in particular, may have a considerable impact on the patients' quality of life (Breitbart et al., 2009; Cowan, 2011; Wahl et al., 2009). A restriction in mobility and declining physical as well as cognitive functions, especially difficulty concentrating, a sense of powerlessness and helplessness are frequent pain-induced complaints (e.g. Breitbart et al., 2009; Melkumova et al., 2011). Such experiences may lead to the intensification of resignation thoughts and suicidality (Breitbart et al., 2009). Furthermore, the available empirical data confirms the concurrence of insomnia and chronic pain (Goral et al., 2010; Tang et al., 2007). What is more, insomnia may in turn intensify pain sensations. Also pain and insomnia are among major risk factors for suicide (Kutcher \& Chehil, 2007).

Apart from physical complaints, other factors contributing to the development of depression are a sense of worthlessness and low self-esteem as well as an impairment of the ability to perform important roles in one's professional and family life, a loss of independence, a sense of meaninglessness and chronic anxiety. Thus it is not surprising that depression is one of the most frequent mental disorders observed among cancer patients. Nearly half of cancer patients suffer from depression and anxiety (cf. Breitbart et al., 2009; Rymaszewska \& Dudek, 2009).

Anxiety can be related to the fear of death, of treatment and its side effects, of adverse impact of the disease on the patient's personal, family and professional life, etc. The disorder frequently manifests itself as a generalized anxiety disorder, worrying or generalized futureoriented anxiety. As an unpleasant experience pain may also lead to the development of the fear of future pain or of the intensification of pain to such an extent that it becomes unbearable (Cowan, 2011; Leeuw et al., 2007).

\subsection{Pain as a source of chronic stress}

\subsubsection{Stress and cognitive appraisal}

Pain intensifies the patients' level of distress (Zaza \& Baine, 2002). Lazarus and Folkman define stress as a "particular relationship between the person and the environment that is appraised by the person as taxing or exceeding his or her resources and endangering his or her well-being" (1984, p. 19).

Crucial in this conception is the subject cognitive appraisal of the relationship between an individual and his or her environment, which is seen as the "process of categorizing an encounter, and its various facets, with respect to its significance for well-being" (Lazarus \& Folkman, 1984, p. 31). This appraisal is a continuous process and embraces the primary appraisal, in which a given situation is recognized as stressful and defined in terms of 
harm/loss, threat or challenge, and the secondary appraisal, which concerns the possible action which can be taken by an individual in order to resolve the situation. Both these appraisals are linked and occur simultaneously.

According to the cognitive behavioural theories regarding the occurrence of emotions and the generation of activities (e.g. Ellis \& Dryden, 2007; Maultsby, 1990), cognitive content informs the person's emotions as well as his or her behaviour. Thus the appraisal of the stressor in the terms of harm/loss is frequently followed by sadness and grief and passive behaviour, threat gives rise to anxiety and escape or erratic behaviours, while challenge may result in a variety of emotions, including positive ones such as hope, which are accompanied by involvement and goal-oriented activities.

\subsubsection{Coping}

The secondary appraisal in turn enables a person to evaluate his or her own possibilities to act when confronted with a stressor, so that the process of coping can commence. Lazarus and Folkman define coping as "constantly changing cognitive and behavioural efforts to manage specific external and/or internal demands that are appraised as taxing or exceeding the resources of the person" (1984, p. 141). Since the appraisal which determines coping is subjective, hence liable to cognitive distortion, coping can be aimed at resolving the problem or at selfregulation of emotions.

Coping itself cannot, however, be equated with the objective adaptability of behaviours. The patient can cope with stress by, for example, following the doctor's recommendations and in so doing reducing the risk of further development of the illness, but, on the other hand, the patient (especially if he or she has a low opinion of their ability to instrumentally resolve the problem) may engage in the activities regarded as unhealthy, such as alcohol consumption, which nevertheless will help them to achieve emotional comfort (cf. Endler, Parker \& Summerfeldt, 1998). Finally, chronic stress can be related to the treatment regimen or the changeable course of the disease. Patients suffering from chronic conditions commonly balance between the instrumental and emotion-regulating activities and hence the catalogue of the techniques they employ to cope with stress is subject to change.

At this point the costs of coping must be mentioned, i.e. the loss of resources following the undertaking and continuing the efforts aimed at dealing with the stressful situation. From the perspective of cost assessment it might prove more cost-effective to abandon the efforts and tolerate the stressors rather than undertake an effort to cope with them (cf. Hobfoll, 1998; Schönpflug \& Battmann, 1988, as cited in Heszen \& Sęk, 2007). In practical terms it means that the patient may choose not to be involved in his or her own treatment, and he or she may experience a sense of hopelessness, reduced activity and lack of motivation to undertake new tasks or challenges.

\subsubsection{Neuropsychological aspect of stress}

Stress and the ways of coping may also impact on neurophysiological processes related to the reaction to stress: on their intensity, frequency, duration and the reaction patterns. Moreover, chronic sympathetic system and hormonal system arousal may in turn lead to the exhaustion of the body's resources, immune deficiency, and functional - and subsequently structural - disorders of the organs and the systems of the body (cf. Vedhara \& Irwin, 2005). Chronic stress leads to the constant activation of the adrenal cortex and the oversecretion of glucocorticosteroids, including cortisol. Although in the case of short-term stress those 
hormones assist the release of additional energy and help to resolve a difficult situation, in the case of prolonged stress they can cause a number of adverse reactions in the body. For instance chronic hypercortisolemia may contribute to the damage and the atrophy of the hippocampus (Colla et al., 2007; Sapolsky, 2000). In the case of pain neuroimaging tests confirm the presence of dysfunctions and structural alterations of the limbic system and hippocampus, which is the structure that suppresses cortisol secretion (Herbert et al., 2006; Zimmerman et al., 2009). What is more, the hippocampus is the region of the brain where the memories of the context of a given situation and the perception of the stimulus are stored and can be retrieved to help a person to appraise the currently experienced events in a more adequate manner. The damage of the hippocampus contributes to the further increase of the stress level, since the reduction of feedback prevents the effective suppression of hormone secretion from the suprarenal gland while the impairment of memory and dysregulation of affect, the functions normally regulated by the hippocampus, result in the patient seeing his or her life as even more miserable (cf. Wirga \& Wojtyna, 2010).

\subsection{Psychological factors and pain}

The intensity of pain is determined by a number of factors and the size of the damaged tissue is only one of them. Nociceptive stimuli are first modified in the spinal cord through so-called "gate control" (Melzack \& Wall, 1965). The interaction of the impulses transmitted by the nerve fibres of various diameter can cause inhibition or intensification of the nociceptive signal. The process is also affected by the impulses coming from the brain. The processes occurring in the central nervous system are of major importance for the chronic pain-related issues.

\subsubsection{Anxiety and pain}

The perception of pain depends on the level of arousal and emotional state. The level of anxiety is crucial here and the reaction to fear and anxiety manifests itself on several levels:

- physiological - as an activation of the sympathetic system, including faster breathing, the activation of the circulatory system as well as increased muscle tone and reactivity;

- cognitive - as an interpretation of the stimulus as a threat and the appraisal of its consequences;

- behavioural - as activities leading to coping with the threat, including escape and avoidance behaviour.

A number of studies indicate that the level of anxiety is the crucial aspect of coping with pain. The studies concerning chronic pain proved that the catastrophizing of this experience contributes to the reactions which additionally intensify the feeling of pain (e.g. Leeuw et al., 2007; Linton et al., 2000; Mok \& Lee, 2008; Nijs et al., 2008). The fear of pain can manifest itself as, for instance, the fear of the feeling of pain itself, the fear of physical activity or movement which can trigger pain or the fear of (re)injury (Leeuw et al., 2007).

Similar phenomena may occur in the case of cancer patients. However, it is not only the fear of pain itself that can contribute to the intensification of sensations of pain, since the physiological symptoms of anxiety, through the increase of muscle tone or intensification of the scanning of one's own body - regardless of the cause of the fear - may also contribute to the alteration of the perception of pain. 


\subsubsection{Hypervigilance and pain}

Pain-related fear may also result in the patient's making an effort to find as much information about the current situation as possible, which leads to so-called hypervigilance: the tendency to scan one's own body and observe its signals. Since the patient's attention is heightened, he or she is likely to notice more disturbing symptoms and perceive the neutral stimuli as painful (cf. Lautenbacher et al., 2010; Rollman, 2009). According to behavioural theories, hypervigilance is reinforced by the patient's relatives and friends, since his or her complaints meet with their attention and care or bring small benefits such as being excused from the chores. From the perspective of cognitive theories, the patient's beliefs concerning the nature of pain and the consequences of his or her disease are of vital importance. The patient may be convinced that pain indicates, for example, the spreading of the cancer and the prompt reaction to even the slightest sensation of pain can help to apply an appropriate procedure and, in consequence, save his or her life. Hypervigilance may also be affected by the vagueness of a painful stimulus. The stimuli whose site and intensity are well defined are less likely to arouse the patient's specific vigilance than the vague ones (e.g. Almay, 1987; Kostarczyk, 2003).

The patient's attitude is of prime importance. The anticipation of suffering contributes to hypervigilance and thus raises the risk of the occurrence and/or intensification of pain (Arntz et al., 1991; Leeuw et al., 2007). On the other hand, the placebo effect represents the opposite phenomenon. It has been demonstrated on numerous occasions that patients who believe in the efficacy of pain treatment feel considerable relief after being given an inert substance (cf. Benedetti, 2009).

\subsubsection{Catastrophizing and pain}

Another significant factor which may modify painful sensations is catastrophizing, which involves anticipating the worst possible outcome of the symptoms experienced and contributes to appraising the situation as a threat as well as preventing the person from believing in his or her ability to cope with the problem (Leeuw et al., 2007; Nijs et al., 2008; Vowles et al., 2008). Catastrophizing is a cognitive disorder linked to the tendency to anticipate the worst-case scenario and overestimate its probability. It also leads to exaggerating the problems and overlooking positive aspects of the situation such as the availability of useful resources. What lies at the roots of this phenomenon is the patient's previous experiences as well as the assumptions concerning a given disease, in this case, cancer and pain. The assumptions are based on the information from the media, public and cultural sources, books, medical specialists as well as a wide variety of other sources. Therefore the assumptions the patient makes about his or her illness may differ significantly from the objective medical knowledge. A number of studies indicate that catastrophizing is closely linked with the intensification of pain and anxiety (Bishop \& Warr, 2003; A.K. Burton et al., 1995), and can even serve as a predictor of the occurrence of pain and the deterioration of the patient's condition, which was demonstrated in the prospective study on back pain (Linton et al., 2000).

\subsubsection{Behaviour and pain}

The fear of pain is commonly followed by avoidance behaviours (Leeuw et al., 2007). It may lead to, for instance, withdrawal from physical activity, which, in the patient's view, may cause (re)injury or contribute in any way to the intensification of pain. Cancer patients may 
also avoid certain medical procedures, such as radiotherapy or chemotherapy. In the short term, the patient may feel relief, but in the long term such behaviour will result in the progress of the disease, the consequence of which is the intensification of pain, or it may lead to the decline in the patient's fitness, fatigue and the increased likelihood of injury, which may also contribute to the occurrence of pain in the future.

\subsubsection{Beck's model of depression}

In the light of the above it is of utmost importance to identify the factors capable of reducing the level of distress, anxiety and depressiveness experienced by cancer patients suffering from chronic pain. Beck's idiosyncratic model of depression can provide a clue here (cf. Beck et al., 1979; Williams, 1997). The model focuses on three aspects. The first one is negative automatic thoughts, which people often take for granted without an in-depth analysis. They bring about mood changes and, as a result, further thoughts and misconceptions arise, which finally leads to the downward spiral of despair. The frequent repetition of such thoughts reinforces them and retains them as patterns in the neural networks of the central nervous system, which increases the risk of clinical depression symptoms in the future (cf. Williams, 1997; Wirga \& Wojtyna, 2010).

Another important aspect of Beck's theory is systematic cognitive distortions present in thinking, such as jumping to arbitrary conclusions, excessive generalization, selective disregard, exaggeration, minimization, dichotomous thinking and, finally, personalization involving attributing certain negative characteristics to oneself despite evidence to the contrary (cf. Wiliams, 1997). Such cognitive errors increase the risk of negative automatic thoughts recurrence and contribute to the further mood lowering.

Finally, the third aspect of Beck's model is the depressiogenic cognitive schema. The schema, according to this theory, is a structure which analyses and organizes information coming from the environment and enables a person to promptly identify the meaning of a given stimulus. The schemata are based on an individual's previous experience, and they typically develop over the years. In the case of depression, the schemata involve long-lasting pessimistic attitudes and negative assumptions about oneself, reality and future (Beck et al., 1979; Williams, 1997). Pain and cancer may in this case act as impulses which activate preexisting schemata.

In conclusion, cognitive content generated in the event of the disease may become the source of stress and mood lowering, which sometimes develops into a clinically diagnosed disorder. Bearing in mind the possibility of systematic cognitive distortions it can be assumed that the individual's emotions and behaviour frequently result from the biased distorted appraisal of the facts. Therefore the emotional-behavioural expression may be inappropriate to the situation.

\subsubsection{Cognitive behavioural therapy}

Thus if the cognitive approach is adopted, the psychological intervention must be based on the refutation of the cognitive distortions, the construction of the appropriate assessment of the situation and the replacement of the thoughts with more functional ones, conducive to the reduction of suffering (cf. Ellis \& Dryden, 2007; Maultsby, 1990). Such interventions are essential for the cognitive behavioural therapy (CBT).

CBT proved very useful in conjunction with oncological treatment (Moorey \& Greer, 2002). Numerous studies proved that CBT helps to alleviate pain or reduce the mental components 
of various somatic complaints, such as pain (Grant \& Haverkamp, 1995; Reid et al., 2003), breathlessness (Bredin et al., 1999), nausea and vomiting (cf. Cathcart, 2006). CBT is beneficial in pain treatment as it helps the patient to cope with complaints more effectively, decreases the perception of symptoms and enables the patient to use analgesic medication less frequently or in smaller doses, which in turn may reduce adverse effects of pharmacotherapy (Syrjala et al., 1995). Complementary psychotherapeutic treatment is of particular importance in the case of neuropathic pain, since many patients continue to experience excruciating pain even after the administration of the analgesics. CBT has been shown to be effective in alleviating pain in those patients.

Despite the evidence from the research conducted to date, the current state of knowledge concerning the possible improvement of the cancer patients' quality of life is still inadequate, particularly as far as pain is concerned. Moreover, little is known about the mechanisms which might lead to such improvement.

\section{The study}

\subsection{Aim}

The main objectives of the following study were to:

- explore the link between the intensity of irrational beliefs, depressiveness and the severity of pain in cancer patients,

- determine the impact of the cognitive behavioural therapy on the perception of pain in cancer patients.

\subsection{Design and subjects}

The longitudinal study comprised a pre-test and a post-test after the period of two months. 253 non-terminal cancer patients participated in the study, all of whom were also treated for chronic pain at the Pain Clinic. All the subjects took advantage of the pharmacological assistance provided by the clinic. 128 patients took part in the cognitive behavioural therapy, while others constituted the control group $(n=125)$ and only took advantage of the standard assistance provided by the Pain Clinic. The group allocation was randomized.

\subsection{The method of intervention - Rational behavioural therapy}

The study employed the cognitive behavioural method known as rational behavioural therapy (Maultsby, 1990). The aim of this method is to isolate the person's beliefs which are chiefly responsible for his or her emotional discomfort. Maultsby proposes that the previously identified beliefs be tested to assess their rationality by means of the rules of healthy (rational) thinking. These rules relate to the following issues:

- Healthy thinking is based on obvious facts. Thus this rule aims at exposing cognitive distortions. In order to do that the patient is engaged into a conversation and a so-called camera test is performed ("if this event was captured on film, what would be recorded? Does it conform with your judgement/opinion?"). The weighing pros and cons discussion can also be used. Finally, the behavioural experiments can be utilized, especially those which involve identifying other people's views.

- Healthy thinking helps protect health and life. This rule refers to the effects a given way of thinking has on somatic health. The question which proves particularly helpful in this case is whether the thought tested helps to reduce the stress level or intensifies it. It 
follows from psychoneuroimmunological knowledge that the prolonged distress will lead to the reduction in immunocompetence (cf. Vedhara \& Irwin, 2005). Therefore, a way of thinking which encourages the reduction of distress should be essential for better health.

- Healthy thinking helps to achieve goals. This rule relates to the motivational sphere. A healthy way of thinking promotes physical activity. The person who thinks in this way is more motivated to act towards desirable ends.

- Healthy thinking helps to resolve or avoid unwanted conflicts. A healthy way of thinking allows the person to maintain desirable relationships with others. It enables the person to cater for his or her own needs and at the same time reduces the risk of undesirable conflicts.

- And finally healthy thinking helps the person to feel the way he or she wants to feel. This rule is also known as "a healthy thinking helps to feel better" or "to feel less unwell". It is worth noting at this point that the mood improvement here follows from cognitive content without the use of psychoactive substances.

Thus the rules of healthy thinking relate to the realistic assessment of facts and the appraisal of the effects of a given way of thinking on the most important areas of a person's functioning: physical health, motivational sphere, interpersonal relations and mental health. According to Maultsby a rational way of thinking is characterized by at least three of the above-mentioned rules. The appraisal of the cognitive content is subjective and performed by the patient him- or herself.

The stage of the identification of irrational beliefs is followed by the search for alternative thoughts which concern the same issue but are more adaptive and are correlated with the improvement of the patient's emotional state. The search for alternatives which will conform with the criteria of healthy thinking involves the discussion with the patients. The therapy based on the rules of healthy thinking is the compilation of several classical techniques employed in CBT, such as the "pros and cons" technique, the appraisal of the consequences of thinking or the refutation of cognitive distortions.

The alternative rational thinking is reinforced through daily repetition of healthy thoughts, finding evidence of their truth and by employing the patient's imagination: he or she imagines a desired outcome and a desired emotional and behavioural state resulting from a new way of thinking.

The current study involved the individual therapy consisting of 8 weekly hour-long sessions.

\subsection{Study instruments \\ 4.4.1 Depression}

The current study used the Polish translation of Beck Depression Inventory (BDI; Beck et al, $1988,1996)$. The inventory can be used to determine the general intensity of depressiveness and the intensity of its following components: affective and somatic symptoms.

The inventory contains 21 questionnaire items. Each item has a set of four possible answer choices, reflecting the range of symptom intensity: from the complete absence of a symptom (value 0 ) to the clear manifestation (value 3). Thus the total score ranges from 0 to 63 , with the higher score indicating more severe depressive symptoms.

The reliability coefficient for Beck Depression Inventory was a $=0.91$, whereas Cronbach's a coefficient for subscales ranged from 0.86 for Somatic subscale to 0.96 for Affective subscale. 


\subsubsection{Pain intensity}

A Visual Analogue Scale (VAS) was used to determine the severity of pain. VAS is a simple instrument to measure the patient's subjective assessment of pain severity. The patient is provided with a 100-millimetre line, on which he or she marks the point which represents the severity of pain he or she feels, with the point 0 indicating the complete absence of pain and 100 - the most severe pain imaginable.

\subsubsection{Irrational beliefs regarding pain}

The study utilized a partly structuralized interview concerning the patient's perception of pain and the possible ways of coping with it. Next the Socratic dialogue was used to find out more details and, as a result, to identify the patient's beliefs concerning pain, which was essential for further therapy. The beliefs were classified as irrational if they were counterfactual (this criterion did not apply to spiritual beliefs) or they failed to conform with at least three of Maultsby's rules of healthy thinking (Maultsby, 1990).

The beliefs were assessed by the patients on the scale of 0 to $100 \%$ to determine the strength of the patients' conviction as well as the intensity of the emotional discomfort associated with a given belief. The level of emotional discomfort was marked on the scale of 0 to 100, where 0 indicated composure and 100 the most severe emotional discomfort.

The intensity of irrational beliefs was assessed in two ways. First, the proportion of irrational beliefs was assessed in reference to the total of patient's statements concerning his or her own person identified in the course of the study. Then, in order to estimate the strength of the patient's irrational beliefs, the mean value of the patient's conviction relating to all previously identified irrational cognitive content was calculated.

\subsubsection{Catastrophizing}

To assess the intensity of catastrophizing with regard to pain the 13-item Pain Catastrophizing Scale (PCS; Sullivan et al., 1995) was used. This instrument is used to calculate the general score as well as the score in three subscales: magnification, rumination, and helplessness.

Patients are asked to report how often they experience certain thoughts or feelings while in pain. The answers are marked on the 5-point Likert scale ranging from 0 (Not at all) to 4 (All the time). Cronbach's a coefficient of reliability for the present study was 0.90 .

\subsubsection{Demographic data}

Demographic data sheet was used to gather information concerning the patients' age, sex, marital status, educational background, professional status, the duration of cancer as well as the patients' specific diagnosis, and the duration for which the patient was registered with the Pain Clinic.

\section{Results}

The characteristics of the group are presented in table 1.

The pre-test showed no differences in the study variables between the experimental and control groups.

The patients' average score in Beck Depression Inventory was 32.57. It is worth noting that as many as $76.1 \%$ of the study subjects scored above 13 , which, according to the authors of the questionnaire, could be interpreted as a high risk of clinical depression (Beck et al., 1996). $11.45 \%$ of the study subjects' score indicated a risk of a major depressive episode. 


\begin{tabular}{|c|c|c|c|}
\hline Characteristics & $\begin{array}{c}\text { CBT group } \\
n=128\end{array}$ & $\begin{array}{c}\text { Control group } \\
\mathrm{n}=125\end{array}$ & $\begin{array}{l}\text { Total } \\
n=253\end{array}$ \\
\hline $\begin{array}{l}\text { Age } \\
\text { Mean } \\
\text { Range }\end{array}$ & $\begin{array}{c}54.12 \\
36-65\end{array}$ & $\begin{array}{c}55.27 \\
39-65\end{array}$ & $\begin{array}{r}54.89 \\
36-65\end{array}$ \\
\hline $\begin{array}{l}\text { Gender [\%] } \\
\text { Male } \\
\text { Female }\end{array}$ & $\begin{array}{l}47.66 \\
52.34\end{array}$ & $\begin{array}{l}47.20 \\
52.80\end{array}$ & $\begin{array}{l}47.43 \\
52.57\end{array}$ \\
\hline $\begin{array}{l}\text { Marital status [\%] } \\
\text { Single } \\
\text { Married } \\
\text { Widowed } \\
\text { Divorced/Separated } \\
\end{array}$ & $\begin{array}{c}1.57 \\
71.09 \\
10.94 \\
16.4 \\
\end{array}$ & $\begin{array}{c}2.4 \\
72.8 \\
9.6 \\
15.2 \\
\end{array}$ & $\begin{array}{c}1.98 \\
71.94 \\
10.27 \\
15.81 \\
\end{array}$ \\
\hline $\begin{array}{l}\text { Educational background [\%] } \\
\text { Elementary } \\
\text { Vocational } \\
\text { Secondary } \\
\text { University }\end{array}$ & $\begin{array}{r}1.56 \\
35.94 \\
38.28 \\
24.22 \\
\end{array}$ & $\begin{array}{c}1.6 \\
32.0 \\
40.0 \\
26.4\end{array}$ & $\begin{array}{c}1.58 \\
33.99 \\
39.13 \\
25.3 \\
\end{array}$ \\
\hline $\begin{array}{l}\text { Occupation }[\%] \\
\text { Employed } \\
\text { Unemployed } \\
\text { Housewife } \\
\text { Retired } \\
\end{array}$ & $\begin{array}{l}9.37 \\
50.0 \\
21.88 \\
18.75\end{array}$ & $\begin{array}{c}8.0 \\
53.6 \\
20.0 \\
18.4\end{array}$ & $\begin{array}{c}8.69 \\
51.78 \\
20.95 \\
18.58\end{array}$ \\
\hline $\begin{array}{l}\text { Duration of cancer [yrs] } \\
\text { Mean } \\
\text { Range }\end{array}$ & $\begin{array}{c}5.17 \\
2-11\end{array}$ & $\begin{array}{c}5.34 \\
1-9.5\end{array}$ & $\begin{array}{c}5.21 \\
1-11\end{array}$ \\
\hline $\begin{array}{l}\text { Duration of chronic pain [yrs] } \\
\text { Mean } \\
\text { Range }\end{array}$ & $\begin{array}{c}1.94 \\
0.5-6\end{array}$ & $\begin{array}{c}2.01 \\
0.5-5.5\end{array}$ & $\begin{array}{c}1.98 \\
0.5-6\end{array}$ \\
\hline $\begin{array}{l}\text { Pain intensity (VAS) } \\
\text { Mean } \\
\text { Range }\end{array}$ & $\begin{array}{c}45.26 \\
10-95\end{array}$ & $\begin{array}{c}44.98 \\
10-90\end{array}$ & $\begin{array}{r}45.07 \\
10-95 \\
\end{array}$ \\
\hline $\begin{array}{l}\text { Depression }(\mathrm{BDI}) \\
\text { Mean } \\
\text { Range }\end{array}$ & $\begin{array}{l}33.28 \\
3-59 \\
\end{array}$ & $\begin{array}{l}32.01 \\
2-57 \\
\end{array}$ & $\begin{array}{l}32.57 \\
2-59 \\
\end{array}$ \\
\hline $\begin{array}{l}\text { Catastrophizing (PCS) } \\
\text { Total } \\
\text { Magnification } \\
\text { Rumination } \\
\text { Helplessness }\end{array}$ & $\begin{array}{c}33.62 \\
7.07 \\
12.34 \\
14.22\end{array}$ & $\begin{array}{c}33.16 \\
6.85 \\
12.01 \\
14.28\end{array}$ & $\begin{array}{c}25.31 \\
6.97 \\
12.18 \\
14.24\end{array}$ \\
\hline $\begin{array}{l}\text { Irrational beliefs } \\
\text { Number (Proportion) [\%] } \\
\text { Conviction the beliefs are true [mean] } \\
\text { Level of emotional discomfort [mean] }\end{array}$ & $\begin{array}{l}70.11 \\
86.78 \\
75.42\end{array}$ & $\begin{array}{l}69.07 \\
88.29 \\
74.30\end{array}$ & $\begin{array}{l}69.51 \\
87.33 \\
74.87\end{array}$ \\
\hline
\end{tabular}

Table 1. Characteristics of study participants 


\begin{tabular}{|c|c|c|}
\hline $\begin{array}{l}\text { Examples of statements } \\
\text { (strength of conviction) }\end{array}$ & $\begin{array}{l}\text { Cognitive } \\
\text { distortions }\end{array}$ & Healthier alternatives \\
\hline $\begin{array}{l}\text { I can't sleep at all because of the } \\
\text { pain }(100 \%)\end{array}$ & Exaggeration & $\begin{array}{l}\text { I can sleep a little in spite of the pain. } \\
\text { I can fall asleep more easily if I concentrate } \\
\text { on other things. }\end{array}$ \\
\hline $\begin{array}{l}\text { I know that pain is a sign of the } \\
\text { advancement of cancer }(100 \%)\end{array}$ & Catastrophizing & $\begin{array}{l}\text { Pain is linked to the disease and treatment. } \\
\text { It indicates that something has happened to } \\
\text { my body, but it does not necessarily mean } \\
\text { that something worse is going on. I can } \\
\text { work with the doctor to control it. }\end{array}$ \\
\hline $\begin{array}{l}\text { Pain destroys my life, I'm going } \\
\text { to be a total wreck }(80 \%)\end{array}$ & $\begin{array}{l}\text { Exaggeration, } \\
\text { catastrophizing }\end{array}$ & $\begin{array}{l}\text { My life goes on in spite of the pain. } \\
\text { I can still be useful and do a lot of things. }\end{array}$ \\
\hline $\begin{array}{l}\text { Even if there is slight relief, } \\
\text { I always feel worse later on. } \\
\text { I can't do what I want anyway } \\
(90 \%)\end{array}$ & $\begin{array}{l}\text { Active refutation } \\
\text { of positive } \\
\text { aspects, } \\
\text { dichotomous } \\
\text { thinking }\end{array}$ & $\begin{array}{l}\text { Sometimes I hurt more and sometimes less. } \\
\text { When I feel better, I can do something I like } \\
\text { or something that I want. } \\
\text { When I do something nice for myself, I feel } \\
\text { even better. } \\
\text { Perhaps if I engage in something that I like, } \\
\text { it will help me to feel better physically. }\end{array}$ \\
\hline $\begin{array}{l}\text { When it hurts so much, I know } \\
\text { the end is near (90\%) }\end{array}$ & Exaggeration & $\begin{array}{l}\text { I don't know what will happen. } \\
\text { Pain is just a symptom and I'm alive and } \\
\text { I should take advantage of that. }\end{array}$ \\
\hline $\begin{array}{l}\text { This pain will never go away. On } \\
\text { the contrary, it'll be worse and } \\
\text { worse }(100 \%)\end{array}$ & $\begin{array}{l}\text { Exaggeration, } \\
\text { catastrophizing }\end{array}$ & $\begin{array}{l}\text { I don't know what will happen. } \\
\text { My pain is sometimes stronger and } \\
\text { sometimes not so strong. } \\
\text { This means that it can be modified } \\
\text { One day I might be able to cope with it } \\
\text { better than now. }\end{array}$ \\
\hline $\begin{array}{l}\text { I've been hurting a little less in } \\
\text { the past couple of days, but it's } \\
\text { just a lucky chance - it must } \\
\text { have been because of the weather } \\
(70 \%)\end{array}$ & Minimization & $\begin{array}{l}\text { I don't know why I've been hurting less. } \\
\text { But if it's possible, it means that this pain } \\
\text { can sometimes be less strong. } \\
\text { I will find the ways to help me to feel } \\
\text { better. } \\
\text { I will concentrate on the periods when I } \\
\text { feel well and try to find out what it is that } \\
\text { helps me. It will help me to organize my } \\
\text { life better. }\end{array}$ \\
\hline $\begin{array}{l}\text { Because of this pain I'm good for } \\
\text { nothing }(90 \%)\end{array}$ & $\begin{array}{l}\text { Generalization, } \\
\text { exaggeration }\end{array}$ & $\begin{array}{l}\text { There are many spheres of life apart from } \\
\text { pain. I can still do a lot of things. }\end{array}$ \\
\hline $\begin{array}{l}\text { This treatment is pointless - it } \\
\text { still hurts like hell. It'd be better } \\
\text { to shoot myself or get drunk and } \\
\text { never get sober }(95 \%)\end{array}$ & $\begin{array}{l}\text { Dichotomous } \\
\text { thinking }\end{array}$ & $\begin{array}{l}\text { My treatment helps me to alleviate pain a } \\
\text { little, so it is efficient to a certain extent. } \\
\text { Perhaps in the meantime they will develop } \\
\text { a better treatment. } \\
\text { Rather than worry myself sick, I can } \\
\text { concentrate on the present moment. }\end{array}$ \\
\hline
\end{tabular}

Table 2. Patients irrational beliefs concerning pain and their healthier alternatives developed in the course of CBT 
The study revealed a variety of irrational cognitive thoughts related to the perception of pain and the possible ways of coping with it. On average as much as $69.51 \%$ of statements concerning pain and coping with it identified in the course of the interview were classified as irrational. At the same time the high value of the patients' conviction that their irrational beliefs are true was observed $(M=87.33 ; S D=7.61)$. The sample of the patients' statements, with the identification of logical errors and their healthier alternatives, are presented in table 2 .

The strong tendency towards catastrophizing and exaggeration of the possible consequences of actual facts is worth noting. Another frequent logical error is dichotomous thinking and generalization, which resulted in the patient's perceiving pain as more severe than it really was.

The analysis of the correlations (Kendall's coefficient tau) demonstrated a positive association between the intensity of irrational beliefs and the level of depressiveness as well as the severity of pain (table 3).

The positive associations between both the level of depressiveness and the intensity of pain on the one hand, and all dimensions of catastrophizing and the proportion of irrational beliefs and the conviction that they are true on the other was demonstrated. It is worth noting, however, that these correlation are stronger in relation to the associations taking into consideration the strength of the patient's conviction that his or her own beliefs are true. Furthermore, it must be stressed that the correlations are stronger for the level of irrational beliefs identified in the interview than for the patients' scores on Pain Catastrophizing Scale.

\begin{tabular}{|c|c|c|c|c|c|}
\hline \multirow[b]{2}{*}{ Factor } & \multirow[b]{2}{*}{ Pain intensity } & \multicolumn{4}{|c|}{ Depression } \\
\hline & & & Total & $\begin{array}{c}\text { Affective } \\
\text { symptoms }\end{array}$ & $\begin{array}{c}\text { Somatic } \\
\text { symptoms }\end{array}$ \\
\hline \multicolumn{6}{|l|}{ Catastrophizing } \\
\hline Total & $0.58 \quad p<0.001$ & 0.48 & $p<0.001$ & $0.50 \quad p<0.001$ & $0.44 p<0.01$ \\
\hline magnification & $0.61 p<0.001$ & 0.42 & $p<0.01$ & $0.51 p<0.001$ & $0.33 p<0.05$ \\
\hline rumination & $0.57 p<0.001$ & 0.45 & $p<0.001$ & $0.46 p<0.01$ & $0.43 p<0.01$ \\
\hline helplessness & $0.55 p<0.001$ & 0.51 & $p<0.001$ & $0.49 p<0.001$ & $0.54 p<0.001$ \\
\hline \multicolumn{6}{|l|}{ Irrational beliefs } \\
\hline Number & $0.74 \quad p<0.001$ & 0.65 & $p<0.001$ & $0.70 \quad p<0.001$ & $0.61 p<0.001$ \\
\hline $\begin{array}{l}\text { Conviction the beliefs } \\
\text { are true }\end{array}$ & $0.77 p<0.001$ & 0.69 & $p<0.001$ & $0.72 p<0.001$ & $0.66 p<0.001$ \\
\hline $\begin{array}{l}\text { Level of emotional } \\
\text { discomfort }\end{array}$ & $0.69 p<0.001$ & 0.61 & $p<0.001$ & $0.58 p<0.001$ & $0.64 p<0.001$ \\
\hline \multicolumn{6}{|l|}{ Depression } \\
\hline Total & $0.56 p<0.001$ & & - & - & - \\
\hline Affective symptoms & $0.55 p<0.001$ & & & & \\
\hline Somatic symptoms & $0.58 p<0.001$ & & & & \\
\hline
\end{tabular}

Table 3. The correlation between irrational beliefs and depression and the intensification of pain in cancer patients

The final post-test showed significant differences in the study variables between the experimental and control groups. In order to demonstrate the differences resulting from the cognitive behavioural therapy, the analysis of variance with repeated measures (ANOVA) was used (table 4). 


\begin{tabular}{|c|c|c|c|c|c|c|c|c|}
\hline \multirow[b]{2}{*}{ Factor } & \multirow[b]{2}{*}{ Group } & \multicolumn{2}{|c|}{ Baseline } & \multicolumn{2}{|c|}{ Post-test } & \multicolumn{3}{|c|}{ Source of variance } \\
\hline & & $M$ & $S D$ & $M$ & $S D$ & $\begin{array}{l}\text { Group } \\
F\left(\eta^{2}\right)\end{array}$ & $\begin{array}{l}\text { Time } \\
F\left(\eta^{2}\right)\end{array}$ & $\begin{array}{c}\text { Group } x \\
\text { Time } \\
F\left(\eta^{2}\right)\end{array}$ \\
\hline \multicolumn{9}{|c|}{ Pain } \\
\hline \multirow[t]{2}{*}{ Pain intensity } & CBT & 45.26 & 3.12 & 37.07 & 2.66 & \multirow{2}{*}{ n.s. } & \multirow{2}{*}{$\begin{array}{l}6.27^{*} \\
(0.14) \\
\end{array}$} & \multirow{2}{*}{$\begin{array}{c}31.54^{* *} \\
(0.42)\end{array}$} \\
\hline & Control & 44.98 & 3.37 & 47.39 & 3.52 & & & \\
\hline \multicolumn{9}{|l|}{ Depression } \\
\hline \multirow[t]{2}{*}{ Total } & CBT & 33.28 & 5.62 & 26.85 & 4.47 & \multirow{2}{*}{ n.s. } & \multirow{2}{*}{ n.s. } & \multirow{2}{*}{$\begin{array}{c}34.61^{* * *} \\
(0.47)\end{array}$} \\
\hline & Control & 32.01 & 4.96 & 33.17 & 4.63 & & & \\
\hline \multirow{2}{*}{$\begin{array}{l}\text { Affective } \\
\text { symptoms }\end{array}$} & CBT & 12.89 & 3.13 & 7.64 & 2.32 & \multirow{2}{*}{ n.s. } & \multirow{2}{*}{ n.s. } & \multirow{2}{*}{$\begin{array}{c}36.87^{* * *} \\
(0.48)\end{array}$} \\
\hline & Control & 12.85 & 2.99 & 13.01 & 2.81 & & & \\
\hline \multirow{2}{*}{$\begin{array}{l}\text { Somatic } \\
\text { symptoms }\end{array}$} & $\mathrm{CBT}$ & 20.37 & 3.84 & 19.22 & 3.17 & \multirow{2}{*}{ n.s. } & \multirow{2}{*}{ n.s. } & \multirow{2}{*}{ n.s. } \\
\hline & Control & 19.92 & 3.01 & 20.15 & 4.22 & & & \\
\hline \multicolumn{9}{|l|}{ Catastrophizing } \\
\hline \multirow[t]{2}{*}{ Total } & CBT & 33.62 & 6.02 & 22.77 & 4.68 & \multirow{2}{*}{ n.s. } & \multirow{2}{*}{ n.s. } & \multirow{2}{*}{$\begin{array}{c}43.73^{* * *} \\
(0.51)\end{array}$} \\
\hline & Control & 33.16 & 5.72 & 33.82 & 5.44 & & & \\
\hline \multirow[t]{2}{*}{ Magnification } & CBT & 7.07 & 1.09 & 4.88 & 0.84 & \multirow{2}{*}{ n.s. } & \multirow{2}{*}{ n.s. } & $48.25^{* * *}$ \\
\hline & Control & 6.85 & 1.11 & 6.93 & 1.45 & & & $(0.54)$ \\
\hline Rumination & $\mathrm{CBT}$ & 12.34 & 2.75 & 8.75 & 1.77 & $n_{c}$ & $5.84^{*}$ & $8.51^{*}$ \\
\hline & Control & 12.01 & 3.02 & 12.89 & 2.78 & 11.s. & $(0.06)$ & $(0.18)$ \\
\hline Helplessness & CBT & 14.22 & 3.17 & 8.12 & 1.62 & & & $54.18^{* * *}$ \\
\hline & Control & 14.28 & 3.33 & 13.99 & 2.61 & n.s. & n.s. & $(0.57)$ \\
\hline Irrational belie & & & & & & & & \\
\hline Number & CBT & 70.11 & 9.23 & 47.69 & 6.56 & & $6.13^{*}$ & $66.04^{* * *}$ \\
\hline & Control & 69.07 & 8.89 & 76.24 & 8.64 & n.s. & $(0.11)$ & $(0.71)$ \\
\hline Conviction the & CBT & 86.78 & 10.36 & 68.54 & 5.87 & & & $64.78^{* * *}$ \\
\hline beliefs are true & Control & 88.29 & 9.90 & 89.10 & 8.92 & n.s. & n.s. & $(0.48)$ \\
\hline Level of & CBT & 75.42 & 6.88 & 73.13 & 5.94 & & & \\
\hline $\begin{array}{l}\text { emotional } \\
\text { discomfort }\end{array}$ & Control & 74.30 & 7.13 & 75.22 & 6.86 & n.s. & n.s. & n.s. \\
\hline
\end{tabular}

Table 4. The impact of cognitive behavioural therapy on the intensity of pain, depressiveness and the irrationality of beliefs

n.s. - not significant; ${ }^{*} \mathrm{p}<0.05^{* *} \mathrm{p}<0.01{ }^{* * *} \mathrm{p}<0.001$

The analysis demonstrated the decreased severity of pain, the decreased tendency towards catastrophizing and the less strong conviction that the irrational beliefs are true as well as lower proportion of irrational statements among the patients in the CBT group. Moreover, the intensity of depressive symptoms related to affective component (but not somatic) was also reported to have diminished.

The control group exhibited a small but significant increase in the proportion of irrational beliefs and the intensity of pain, whereas no changes in depressiveness or catastrophizing were observed. 


\section{Discussion}

The results confirm the significance of catastrophizing in the intensification of sensations of pain. At the same time the importance of CBT (restructuring patient's beliefs) for the reduction of depressiveness and the severity of pain was demonstrated. This observation points to the fact that the depressiveness in cancer patients suffering from chronic pain is to a large extent determined by situational rather than endogenous factors. It follows that the pharmacological treatment offered to cancer patients should be complemented by psychotherapy. Furthermore, since the link between the intensity of the irrational beliefs regarding pain and the perceived severity of pain has been established, it appears reasonable to recommend behavioural therapy.

The decrease in the tendency towards catastrophizing helps patients to seek activities which might contribute to the improvement of their quality of life. The healthier alternative thoughts expressed in the course of the therapy included the following: "I can do a lot in spite of the pain"; "Now I can do things I've never had time for"; "There are a lot of things in my body that function properly and I can take advantage of that"; "Actually I live here and now, in this moment. And the pain which lasts a second can be easily endured". The last statement points out the beneficial effect of the shortening of the time (temporal) span to the very short period of time.

The healthier alternatives also included the references to the efficacy of the pain medication. The patients' expectations that the medication will help to alleviate their pain increase the probability of it happening. The phenomenon is similar to the placebo effect. A number of studies (cf. Benedetti, 2009) demonstrated that in the chronic pain treatment the patient's expectations concerning the efficacy of the medication significantly improve his or her general condition. During the 13-week observation of the patients suffering from chronic back pain no significant differences in pain severity were observed between the patients who were administered duloxetine and those given placebo (Skljarevski et al., 2009). A number of studies have found that the administration of placebo reduces the severity of pain in a substantial proportion of patients suffering from chronic pain. It is also reported (Wasan et al., 2006) that the patients who show more severe psychopathological symptoms are more susceptible to the placebo effect with regard to the alleviation of chronic back pain. In the current study the patients exhibited more - although not radically - intense depressive symptoms. Therefore, it can be surmised that they are also particularly susceptible to suggestions concerning the efficacy of pharmacology. In the case of the current study, however, we deal with autosuggestion and actual medication rather than placebo.

Finally, it is worth noting that the condition of the patients was more adequately characterized by the strength of irrationality of beliefs identified in the interview rather than the level of catastrophizing determined on the basis of the questionnaire. This observation should encourage researcher to utilize qualitative methods in preference to paper-pencil tests. It follows from the fact that questionnaires, even those of high accuracy, may provide the indicators of the frequency of symptoms and their severity, but they overlook the significance attached to the symptoms by the patient him- or herself. A questionnaire might fail to cover the issues which, because of their significance for the study subject, will be strongly associated with the phenomenon studied.

\section{Conclusions}

The study confirms the significance of cognitive content in the perception of pain and the development of depressiveness. By reducing the irrationality of thinking cognitive 
behavioural therapy can help to improve the mental and somatic functioning of cancer patients suffering from chronic pain. Therefore, the introduction of CBT as an complementary treatment in conjunction with traditional pharmacological treatment is worth considering.

Irrespective of their therapeutic outcomes, the methods of cognitive behavioural interview can be more effective than a questionnaire in isolating those patients to whom psychotherapeutic techniques may be particularly beneficial, as it has been found that the irrational beliefs identified in the interview served as a better predictor of sensations of pain than the catastrophizing tested by means of the questionnaire.

Cognitive restructuring in the patients suffering from chronic pain can help them to avoid unnecessary irrational suffering and alleviate both physical pain and despair.

\section{References}

Almay, B.G. (1987). Clinical characteristics of patients with idiopathic pain syndromes: Depressive symptomatology and patient pain drawings. Pain, Vol. 29, No. 3, 335346

Armstrong, T., Almadrones, L. \& Gilbert, M.R. (2005). Chemotherapy-induced peripheral neuropathy. Oncology Nursing Forum, Vol. 32, No. 2, pp. 305-311

Arntz, A., Dreessen, L. \& Merckelbach, H. (1991). Attention, not anxiety, influences pain. Behaviour Research and Therapy, Vol. 29, No. 1, pp. 41-50

Beck, A.T., Rush, A.J., Shaw, B.F. \& Emery, G. (1979). Cognitive therapy of depression. Guilford Press, New York

Beck, A.T., Steer, R.A. \& Brown, G.K. (1996). Manual for the BDI-II. The Psychological Corporation, San Antonio, TX

Beck, A.T., Steer, R.A. \& Garbin, M.G. (1988). Psychometric properties of the Beck Depression Inventory: Twenty-five years of evaluation. Clinical Psychology Review, Vol. 8, No. 1, pp. 77-100

Benedetti, F. (2009). Placebo effects. Oxford University Press, ISBN: 978-0-19-955912-1, Oxford

Bishop, S.R. \& Warr, D. (2003). Coping, catastrophizing and chronic pain in breast cancer. Journal of Behavioural Medicine, Vol. 26, No. 3, pp. 265-281

Bredin, M., Corner, J., Krishnasamy, M., Plant, H., Bailey, C. \& A'Hern, R. (1999). Multicentre randomised controlled trial of nursing intervention for breathlessness in patients with lung cancer. BMJ, Vol. 318, No. 7188, pp. 901-904

Breitbart, W., Passik, S.D., Casper, D.J., Starr, T.D. \& Rogak, L.J. (2009). Psychiatric aspects of pain management in patients with advanced cancer and AIDS, In: Handbook of psychiatry in palliative medicine (2 ed.), Chochinov, H.M. \& Breitbart, W. (Eds.)., pp. 384-416, Oxford University Press, ISBN: 978-0-19-530107-6, New York

Burton, A.K., Tillotson, K.M., Main, C.J. \& Hollis, S. (1995). Psychosocial predictors of outcome in acute and subchronic low back trouble. Spine, Vol. 20, No. 6, pp. 722728

Burton, A.W., Fanciullo, G.J., Beasley, R.D. \& Fisch, M.J. (2007). Chronic pain in the cancer survivor: a new frontier. Pain Medicine, Vol. 8, No. 2, pp. 189-198

Cathcart, F. (2006). Psychological distress in patients with advanced cancer. Clinical Medicine, Vol. 6, No. 2, pp. 148-50

Chapman, S. (2011). Chronic pain syndromes in cancer survivors. Nursing Standard, Vol. 25, No. 21, pp. 35-41 
Colla, M., Kronenberg, G., Deuschle, M., Meichel, K., Hagen, T., Bohrer, M. \& Heuser, I. (2007). Hippocampal volume reduction and HPA-system activity in major depression. Journal of Psychiatric Research, Vol. 41, No. 7, (Oct 2007), pp. 553-560

Colyer, H. (2003). The context of radiotherapy care, In: Supportive care in radiotherapy, Faithful, S. \& Wells, M. (Eds.), pp. 1-16, Churchill Livingstone, Edinburgh

Cowan, P. (2011). Living with chronic pain. Quality of Life Research: An International Journal of Quality of Life Aspects of Treatment, Care and Rehabilitation, Vol. 20, No. 3, pp. 307-308

Ellis, A. \& Dryden, W. (2007). The practice of rational emotive behavior therapy (2 ed.), Springer Publishing Company, ISBN: 0-8261-5471-9, New York

Endler, N.S., Parker, J.D.A. \& Summerfeldt, L.J. (1998). Coping with health problems: developing a reliable and valid multidimensional measure. Psychological Assessment, Vol. 10, No. 3, pp. 195-205

Goral, A., Lipsitz, J.D. \& Gross, R. (2010). The relationship of chronic pain with and without comorbid psychiatric disorder to sleep disturbance and health care utilization: Results from the Israel National Health Survey. Journal of Psychosomatic Research, Vol. 69, No. 5, pp. 449-457

Grant, L.D. \& Haverkamp, B.E. (1995). A cognitive-behavioral approach to chronic pain management. Journal of Counseling \& Development, Vol. 74, No. 1, pp. 25-32

Herbert, J., Goodyer, I.M., Grossman, A.B., Hastings, M.H., de Kloet, E.R., Lightman, S.L., Lupien, S.J., Roozendaal, B. \& Seckl, J.R. (2006). Do corticosteroids damage the brain? Journal of Neuroendocrinology, Vol. 18, No. 6, pp. 393-411

Heszen, I. \& Sęk, H. (2007). Psychologia zdrowia [Health psychology], PWN, Warsaw

Hobfoll, S. (1998). Stress, culture and community. The psychology and philosophy of stress. Plenum Press, ISBN: 0306459426, New York and London

Kostarczyk, E. (2003). Neuropsychologia bólu [Neuropsychology of pain]. PTPN, Poznań

Kutcher, S. \& Chehil, S. (2007). Suicide risk management. A manual for Health Professionals. Blackwell Publishing, Oxford

Lautenbacher, S. Huber, C., Schöfer, D., Kunz, M., Parthum, A., Weber, P., Roman, C., Griessinger, N. \& Sittl, R. (2010). Attentional and emotional mechanisms related to pain as predictors of chronic postoperative pain: A comparison with other psychological and physiological predictors. Pain, Vol. 151, No. 3, pp. $722-731$

Lazarus, R. \& Folkman, S. (1984). Stress, appraisal and coping, Springer-Verlag, New York

Leeuw, M., Goossens, M.E., Linton, S., Crombez, G., Boersma, K. \& Vlaeyen, J.W.S. (2007). The fear-avoidance model of musculoskeletal pain: Current state of scientific evidence. Journal of Behavioral Medicine, Vol. 30, No. 1, pp. 77-94

Linton, S.J., Buer, N., Vlaeyen, J. \& Hellsing, A-L. (2000). Are fear-avoidance beliefs related to the inception of an episode of back pain? A prospective study. Psychology and Health, Vol. 14, No. 6, pp. 1051-1059

Maultsby, M.C. (1990). Rational behavior therapy. Rational Self-Help Books/I'ACT, ISBN 0932838-08-1, Appleton

Melkumova, K.A., Podchufarova, E.V. \& Yakhno, N.N. (2011). Characteristics of cognitive functions in patients with chronic spinal pain. Neuroscience and Behavioral Physiology, Vol. 41, No. 1, pp. 42-46

Melzack, R. \& Wall, P.D. (1965). Pain mechanisms: a new theory. Science, Vol. 150, No. 699, pp. 971-979. 
Mok, L.C. \& Lee, I.F-K. (2008). Anxiety, depression and pain intensity in patients with low back pain who are admitted to acute care hospitals. Journal of Clinical Nursing, Vol. 17, No. 11, pp. 1471-1480

Moorey, S. \& Greer, S. (2002). Cognitive behaviour therapy for people with cancer. Oxford University Press, ISBN: 0-19-8508866-2, Oxford

Nijs, J., Van de Putte, K., Louckx, F., Truijen, S. \& De Meirleir, K. (2008). Exercise performance and chronic pain in chronic fatigue syndrome: The role of pain catastrophizing. Pain Medicine, Vol. 9, No. 8, pp. 1164-1172

Reid, M.C., Otis, J., Barry, L.C. \& Kerns, R.D. (2003). Cognitive-behavioral therapy for chronic low back pain in older persons: a preliminary study. Pain Medicine, Vol. 4, No. 3, pp. 223-230

Rollman, G.B. (2009). Perspectives on hypervigilance. Pain, Vol. 141, No. 3, pp. 183-184

Rymaszewska, J. \& Dudek, D. (2009). Zaburzenia psychiczne w chorobach somatycznych [Mental disorders in the somatic illness], Via Medica, ISBN: 978-83-7599-045-4, Gdańsk

Sapolsky, R.M. (2000). Glucocorticoids and hippocampal atrophy in neuropsychiatric disorders. Archives of General Psychiatry, Vol. 57, No. 10, pp. 925-935

Skljarevski, V., Ossanna, M., Liu-Seifert, H., Zhang, Q., Chappell, A., Iyengar, S., Detke, M. \& Backonja, M. (2009). A double-bind, randomized trial of duloxetine versus placebo in management of chronic low back pain. European Journal of Neurology, Vol. 16, No. 9, pp. 1041-1048

Sullivan, M.J.L., Bishop, S. \& Pivik, J. (1995). The Pain Catastrophizing Scale: Developmental and validation. Psychological Assessment, Vol. 7, No. 4, pp. 524-532

Syrjala, K.L., Donaldson, G.W., Davis, M.W. Kippes, M.E. \& Carr, J.E. (1995). Relaxation and imagery and cognitive-behavioral training reduce pain during cancer treatment: a controlled clinical trial. Pain, Vol. 6, No. 2, pp. 189-198

Tang, N.K., Wright, K.J. \& Salkovskis, P.M. (2007). Prevalence and correlates of clinical insomnia co-occuring with chronic back pain. Journal of Sleep Research, Vol. 16, No. 1, pp. 85-95

van den Beuken-van Everdingen, M.H., de Rijke, J.M., Kessels, A.G., Schouten, H.C., van Kleef, M. \& Patijn, J. (2007). Prevalence of pain in patients with cancer: a systematic review of the past 40 years. Annals of Oncology, Vol. 18, No. 9, pp. 1437-1449.

Vedhara, K. \& Irwin, M. (Eds.) (2005). Human psychoneuroimmunology. Oxford University Press, ISBN: 0-19-852840-X, Oxford

Visovsky, C., Collins, M., Abbott, L., Aschenbrenner, J. \& Hart, C. (2007). Putting evidence into practice: evidence-based interventions for chemotherapy-induced peripheral neuropathy. Clinical Journal of Oncology Nursing, Vol. 11, No. 6, pp. 901-913

Vowles, K.E., McCracken, L.M. \& Eccleston, C. (2008). Patient functioning and catastrophizing in chronic pain: The mediating effects of acceptance. Health Psyhology, Vol. 27, No. 2 (Suppl), pp. S136-S143

Wahl, A.K., Rustøen, T., Rokne, B., Lerdal, A., Knudsen, Ø., Miaskowski, C. \& Moum, T. (2009). The complexity of the relationship between chronic pain and quality of life: a study of the general Norwegian population. Quality of Life Research: An International Journal of Quality of Life Aspects of Treatment, Care and Rehabilitation, Vol. 18, No. 8, pp. $971-980$ 
Wasan, A.D., Kaptchuk, T.J., Davar, G. \& Jamison, R.N. (2006). The association between psychopathology and placebo analgesia in patients with discogenic low back pain. Pain Medicine, Vol. 7, No. 3, pp. 217-228

Wiliams, J. M. G. (1997). Depression. In: Science and practice of cognitive behaviour therapy, Clark, D.M. \& Fairburn C.G. (Eds.), pp.259-284, Oxford University Press, Oxford

Wirga, M. \& Wojtyna, E. (2010). Udręki zdrowego umysłu. Neuropsychologia cierpienia [Suffering of healthy mind. Neuropsychology of suffering], In: Wielowymiarowość cierpienia [Many-sidedness of suffering], Binnebesel, J., Błeszyński, J. \& Domżał, Z. (Eds.), pp.31-51, Wydawnictwo Naukowe WSEZ, Łódź

Witte, W. \& Stein, C. (2010). History, definitions, and contemporary viewpoints. In: Guide to pain management in low-resource settings, Kopf, A. \& Patel, N.B. (Eds.), pp. 3-7, International Association for the Study of Pain, retrieved from www.iasppain.org/AM/Template.cfm?Section=Home\&Template=/CM/ContentDisplay.cf $\mathrm{m} \&$ ContentID $=12172$

Zaza, C. \& Baine, N. (2002). Cancer pain and psychosocial factors: A critical review of the literature. Journal of Pain and Symptom Management, Vol. 24, No. 5, pp. 526-542

Zimmerman, M.E., Pan, J.W., Hetherington, H.P., Lipton, M.L., Baigi, K. \& Lipton, R.B. (2009). Hippocampal correlates of pain in healthy elderly adults: A pilot study. Neurology, Vol. 73, No. 19, pp. 1567-1570 


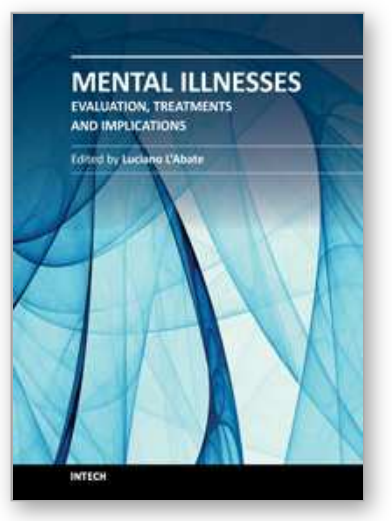

\author{
Mental IIInesses - Evaluation, Treatments and Implications \\ Edited by Prof. Luciano LAbate
}

ISBN 978-953-307-645-4

Hard cover, 476 pages

Publisher InTech

Published online 13, January, 2012

Published in print edition January, 2012

In the book "Mental Illnesses - Evaluation, Treatments and Implications" attention is focused on background factors underlying mental illness. It is crucial that mental illness be evaluated thoroughly if we want to understand its nature, predict its long-term outcome, and treat it with specific rather than generic treatment, such as pharmacotherapy for instance. Additionally, community-wide and cognitive-behavioral approaches need to be combined to decrease the severity of symptoms of mental illness. Unfortunately, those who should profit the most by combination of treatments, often times refuse treatment or show poor adherence to treatment maintenance. Most importantly, what are the implications of the above for the mental health community? Mental illness cannot be treated with one single form of treatment. Combined individual, community, and socially-oriented treatments, including recent distance-writing technologies will hopefully allow a more integrated approach to decrease mental illness world-wide.

\title{
How to reference
}

In order to correctly reference this scholarly work, feel free to copy and paste the following:

Ewa Wojtyna (2012). Irrational Suffering - An Impact of Cognitive Behavioural Therapy on the Depression Level and the Perception of Pain in Cancer Patients, Mental Illnesses - Evaluation, Treatments and Implications, Prof. Luciano LAbate (Ed.), ISBN: 978-953-307-645-4, InTech, Available from:

http://www.intechopen.com/books/mental-illnesses-evaluation-treatments-and-implications/irrational-sufferingan-impact-of-cognitive-behavioural-therapy-on-the-depression-level-and-the-perc

\section{INTECH}

open science | open minds

\section{InTech Europe}

University Campus STeP Ri

Slavka Krautzeka 83/A

51000 Rijeka, Croatia

Phone: +385 (51) 770447

Fax: +385 (51) 686166

www.intechopen.com

\section{InTech China}

Unit 405, Office Block, Hotel Equatorial Shanghai

No.65, Yan An Road (West), Shanghai, 200040, China

中国上海市延安西路65号上海国际贵都大饭店办公楼 405 单元

Phone: +86-21-62489820

Fax: $+86-21-62489821$ 
(C) 2012 The Author(s). Licensee IntechOpen. This is an open access article distributed under the terms of the Creative Commons Attribution 3.0 License, which permits unrestricted use, distribution, and reproduction in any medium, provided the original work is properly cited. 